\title{
Tectonic framework for the Cenozoic cratonic basins of Australia
}

\author{
M. SANDIFORD ${ }^{*}$, M. QUIGLEY ${ }^{1}$, P. DE BROEKERT ${ }^{2}$ AND S. JAKICA $^{1}$
}

\author{
${ }^{1}$ School of Earth Sciences, University of Melbourne, Vic. 3010, Australia.
}

210 Carrick Street, Woodlands, WA 6018, Australia.

\begin{abstract}
Variations in the extent of Cenozoic marine inundation of Australia, as revealed by the distribution of marine and nearshore deposits, points to a tectonic regime involving three distinct modes of deformation. At the longest wavelengths (order $10^{3} \mathrm{~km}$ ), the continent has experienced southwest-up, northeast-down tilting with an amplitude of $~ 300 \mathrm{~m}$ since the Late Eocene. We attribute this tilting to the dynamic topographic response to the northward motion of Australia towards the subduction realm of Indonesia and the western Pacific, as well as its passage across a complexly structured mantle. At short wavelengths (order $10^{1} \mathrm{~km}$ ), variations in elevation are associated with cumulative fault movements up to the order of $100 \mathrm{~m}$. Fault-slip vectors are generally compatible with the prevailing in situ stress field and therefore can be allied to distant plate-boundary forcing. At intermediate wavelengths (order $10^{2} \mathrm{~km}$ ), undulations with amplitudes of the order of $100 \mathrm{~m}$ reflect, at least in part, lithospheric buckling due to relatively high levels of intraplate stress arising from plate-boundary forcing. Understanding the patterns of surface deformation associated with each of these deformation modes provides a tectonic framework against which the broader significance of the Australian Cenozoic record for such things as eustasy must be evaluated.
\end{abstract}

KEY WORDS: Australia, Cenozoic, in situ stress, intraplate deformation, sedimentary basins, tectonic geomorphology.

\section{INTRODUCTION}

The distribution of Cenozoic marine and nearshore sediments around the Australian continent provides a powerful testament to relative changes in sea-levels over the last $50 \mathrm{Ma}$. As would be expected for a stable continent situated in an intraplate tectonic setting, a key factor in controlling the distribution of Cenozoic sedimentation has been a long-term eustatic regressive regime associated with the progressive development of the 'ice-house' world in the latter part of the Cenozoic. This is most spectacularly evidenced by the Nullarbor Plain, as well as numerous other places along the southern coastline of the continent, where Cenozoic marine sediments extend hundreds of kilometres inland from the present-day shoreline. However, the present distribution of Cenozoic sediments also indicates significant differentials in vertical motion within the Australian continent during the Cenozoic. This is most startlingly evidenced by the north-south asymmetry in the elevation of marine sediments around the modern Australian coastline. Whereas the extensive distribution of marine sediments onshore along the southern margin indicates widespread inundation in the Early to mid-Cenozoic, with marine sediments found to elevations locally now up to $\sim 300 \mathrm{~m}$ ASL (above present-day sea-level), the almost complete lack of onshore marine sediments along the northern margin implies present sea-levels are now as high, relative to the continent, as at any time during the Cenozoic.

The elevation of Cenozoic paleoshorelines around the Australian continent, as deciphered from the record of marine and nearshore deposits, varies at a variety of length-scales, from the continental scale (order $10^{3} \mathrm{~km}$ ) to the scale of individual fault blocks (order $10^{1} \mathrm{~km}$ ). In this contribution we propose that a number of distinct tectonic processes, or deformation modes, are responsible for the vertical deformation at the different lengthscales. Understanding the characteristics of these modes, such as their temporal and spatial patterns in topographic expression, is fundamental to understanding the broader significance of the Australian Cenozoic record. For example, any unambiguous picture of the global eustatic sea-level variations must explicitly address the impact of the apparent, long-wavelength, deformation mode. For the Australian Cenozoic, there is strong evidence that such long-wavelength dynamic topographic effects contribute at least as much apparent sea-level variation as do eustatic processes, reflecting the fact that Australia is a relatively fast-moving continent traversing a complexly structured deeper

*Corresponding author: mikes@unimelb.edu.au 
mantle. Our objective is to explore the various modes of deformation that have helped shape the surface of the Australian continent during the Cenozoic, particularly those that have impacted on the distribution of Cenozoic sediments around the periphery of the continent. Our focus is particularly directed to those regions that have largely been immune from ongoing subsidence related to prior continental margin rifting events associated with the fragmentation of the Gondwana in the Mesozoic. In this context, we focus on such regions as the onshore Eucla and Murray Basins in southern Australia and the Karumba Basin in northern Australia, which may be classed as cratonic basins. We provide only a brief summary of the most important constraints on the nature of tectonic movements as evidenced by the present-day distribution of marine and nearshore Cenozoic sediments.

Our analysis highlights three apparently distinct modes that have deformed the interior of the Australian continent since the onset of fast spreading in the Southern Ocean since $43 \mathrm{Ma}$, at the time when the modern IndoAustralian Plate formed by the amalgamation of the preexisting Indian and Australian Plates (Veevers 2000). These three modes are: (i) a long-wavelength (order $10^{3} \mathrm{~km}$ ) continental-scale tilting-mode; (ii) a shortwavelength (order $10^{1} \mathrm{~km}$ ) seismogenic-mode; and (iii) an intermediate-wavelength (order $10^{2} \mathrm{~km}$ ) bucklingmode. In describing these three deformation modes we seek to provide an insight into how they relate to the larger-scale dynamics of the Indo-Australian Plate. Our analysis makes use of the shuttle radar topography mission 3-arc second digital elevation data (SRTM3). The SRTM3 data reveals an unprecedented view of the Australian topographic field at horizontal resolutions of about $90 \mathrm{~m}$ and vertical resolutions estimated at less than $16 \mathrm{~m}$. In view of this, we cite elevation data to the nearest $10 \mathrm{~m}$ contour.

\section{BRIEF SYNOPSIS OF THE AUSTRALIAN ONSHORE RECORD OF CENOZOIC MARINE INUNDATION}

As recently summarised by Sandiford (2007), the distribution of marine and nearshore Cenozoic sediments provides an insight into differential vertical movements of the crust around the Australian continent, revealing a strong asymmetry in vertical motions with respect to the present-day coastline. Along the southern margin, extensive onshore marine deposits indicate periodic inundation prior to $c a 15 \mathrm{Ma}$, and again in a more limited fashion after $c a 6 \mathrm{Ma}$. Maximum marine incursions often extend several hundred kilometres inland of the present-day southern coast, to elevations now several hundred metres ASL. In contrast, equivalentaged marine sediments are mostly absent from the present-day onshore northern margin and eastern margins, or limited to elevations less than $\sim 10 \mathrm{~m}$ ASL, with most interpretations placing Cenozoic shorelines offshore (Veevers 1984, 2000) (Figure 1). Here we provide a brief synopsis relevant to the subsequent discussion of the tectonic processes that have contributed to the deformation of the Australian continent over the last $43 \mathrm{Ma}$.
Along the southern margin of the continent, the most extensive inundation is evident on the Nullarbor Plain, which constitutes the onshore part of the Eucla Basin, and in the Murray Basin (Figure 1). In the Eucla Basin, the northernmost extent of inundation is delineated by a set of paleoshorelines (Figure 2). Along the northwestern Eucla Basin margin, Eocene ( $c a 41 \mathrm{Ma}$ ) paleoshorelines occur at elevations now up to $\sim 300 \mathrm{~m}$ ASL (de Broekert \& Sandiford 2005), while younger Miocene ( $>15 \mathrm{Ma}$ ) shorelines associated with deposition of the Nullarbor Limestone are some $80 \mathrm{~m}$ lower (Hou et al. 2003, 2006, 2008) (Figure 3a). As shown in Figure $3 \mathrm{~b}$, the elevations of these paleoshorelines drop systematically eastwards over a distance of $\sim 1000 \mathrm{~km}$ across the Nullarbor Plain; down to about $150 \mathrm{~m}$ ASL for the Eocene paleoshorelines and down to about $60 \mathrm{~m} \mathrm{ASL}$ for the Miocene shorelines. Pliocene marine sequences in the Eucla Basin are restricted to elevations less than about $30 \mathrm{~m}$ ASL on the Roe Plain (Figure 2). While small fault-related offsets are clearly observable on the Nullarbor Plain (Figure 2), a notable feature of the Eocene coastal barrier systems is the systematic longwavelength variation in elevation that implies a differential vertical tectonic motion with amplitude of order $10^{3} \mathrm{~km}$ (Figure 3b). Inset-valleys (paleochannels) also provide strong evidence for uplift of the Eucla Basin and indeed the Yilgarn Craton during the Cenozoic (de Broekert \& Sandiford 2005).

The Murray Basin was extensively flooded in the Early to mid-Cenozoic, up until ca $15 \mathrm{Ma}$, and again after ca $6 \mathrm{Ma}$ (Brown \& Stephenson 1991). The Pliocene sequences are evident in a strandplain comprising over 150 individual arcuate shorelines clearly evident in the SRTM3 data (Brown \& Stephenson 1991; Roy et al. 2000) (Figure 4). The limit of Pliocene flooding approximately coincides with earlier flooding levels inferred from the distribution of Oligocene to mid-Miocene limestones. In the central part of the basin the maximum marine incursions corresponds to the $70 \mathrm{~m}$ ASL contour (Brown \& Stephenson 1991). In the southern parts of the basin, where the Murray Basin onlaps onto the western Victorian highlands, the Pliocene strandlines occur at elevations up to $\sim 180 \mathrm{~m}$ ASL (Sandiford 2003b; Wallace et al. 2005) along the southern end of a southeasttrending ridge termed the 'Padthaway high' (Figure 4). The order $10^{2} \mathrm{~km}$ wavelength Padthaway high arch has risen about $110 \mathrm{~m}$ relative to the more internal parts of the basin. Quaternary shorelines along its southern flank on the Gambier Plain indicates uplift at a rate of $\sim 75 \mathrm{~m} / \mathrm{Ma}$ from $\mathrm{ca} 780 \mathrm{ka}$ to the present day (Sprigg 1979; Huntley et al. 1993) (Figure 5).

On the northern flanks of the Otway Ranges in southern Victoria, Oligocene-Miocene limestones and Pliocene marine and shoreface deposits step up across a set of east-northeast-trending faults from $\sim 120 \mathrm{~m}$ to $240 \mathrm{~m}$ ASL (Dickinson et al. 2002; Sandiford 2003b; Wallace et al. 2005). Similar fault-related offsets are observed around the Mt Lofty Ranges in South Australia where the elevation of Oligocene-Miocene limestones varies from near sea-level to up to $190 \mathrm{~m}$ across rangebounding faults such as the Willunga Fault (Sandiford 2003a). In what is arguably the most spectacular example of Cenozoic deformation to be seen in 


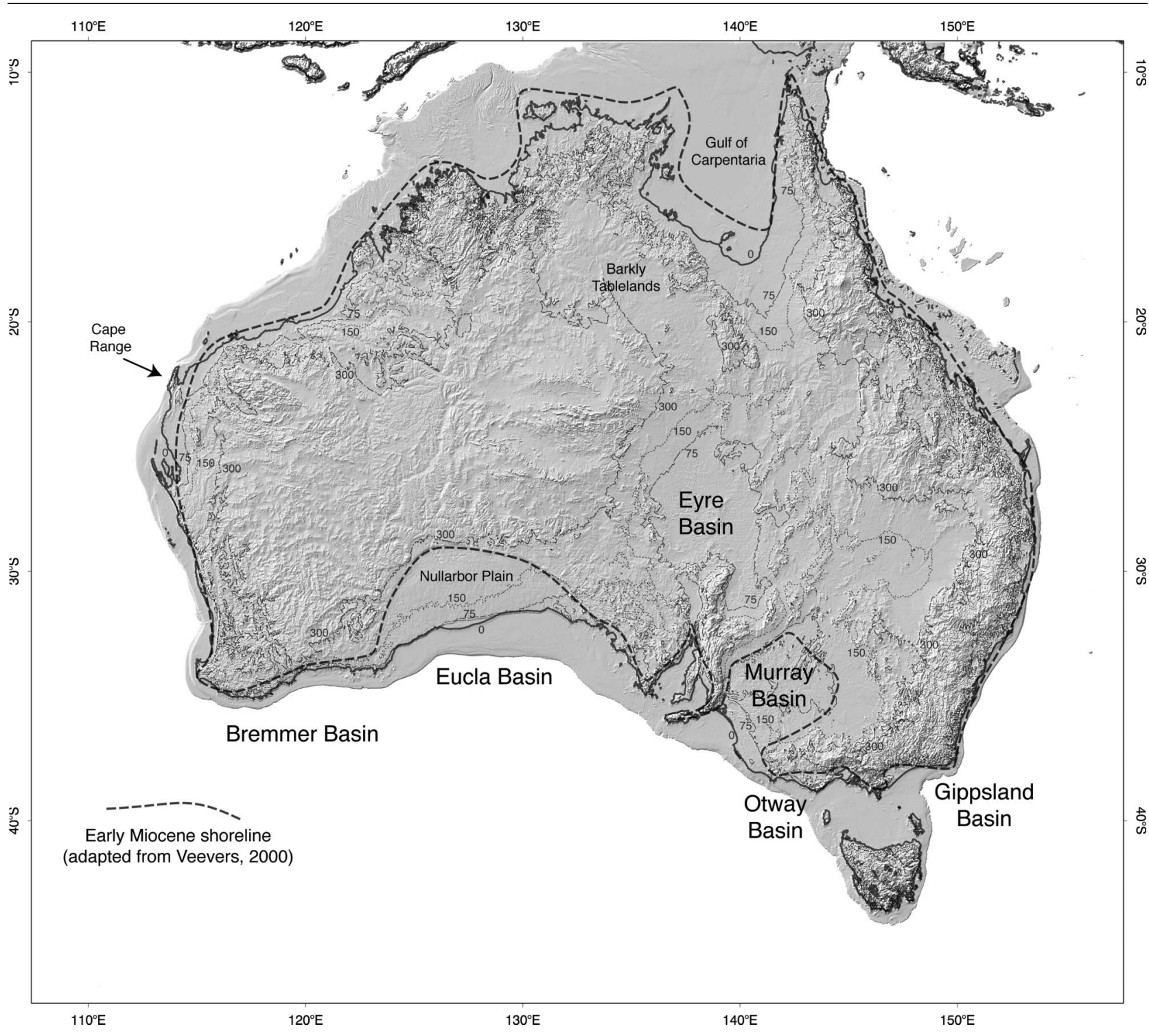

Figure 1 Shaded relief image of the Australian continent and its continental shelf (at elevations greater than $-250 \mathrm{~m}$ ) derived from Geoscience Australia's 9 arc second 'bathytopo' dataset. Contours are shown for $+75,+150$ and $+300 \mathrm{~m}$. The thick dashed line shows the approximate position of Early Miocene shorelines (adapted from Veevers 2000).

Australia, near-vertical Oligocene-Miocene limestones are exposed on shore platforms $50 \mathrm{~km}$ south of Adelaide in the footwall of the Willunga Fault (Figure 6), with correlative sequences in the hangingwall just a few kilometres inland now at elevations of $190 \mathrm{~m}$ ASL. In these locations, differences in elevations of Cenozoic sedimentary sequences can clearly be related to fault movements with individual fault blocks having dimensions of order $10^{1} \mathrm{~km}$. Exposures of these faults show that they are reverse faults with characteristic dips of $\sim 50^{\circ}$ (Williams 1973; Bourman \& Lindsay 1988; Quigley et al. 2006). In the Flinders Ranges, quantitative measures of erosion rates of order $100 \mathrm{~m} / \mathrm{Ma}$ derived from cosmogenic dating provide constraints on relief production by active faulting over the last few million years (Quigley et al. 2007a, b), consistent with cumulative fault motions in excess of $100 \mathrm{~m}$.

Apart from the extraordinary Cenozoic marine sedimentary blanket that covers much of the onshore southern margin, Early to mid-Cenozoic sequences of unequivocal marine origin at significant levels above present-day sea-level are known only from the North West Cape region on the western seaboard (Quilty 1977). Here, Miocene limestones are exposed in a north-northeast-trending antiformal culmination up to $250 \mathrm{~m}$ ASL that defines the Cape Range (Hillis et al. 2008). Seismic reflection profiling across the offshore northern continuation of the Cape Range anticline clearly relate it to subsurface reverse faulting (Hillis et al. 2008).

In view of an almost complete lack of onshore exposure of marine deposits along the northern and eastern margins of the continent, the precise location of Cenozoic shorelines is poorly constrained. An implication is that the present-day sea-levels are, relative to the continent, as high as at any time during the Cenozoic. Based on interpolations derived from the coastward thinning of offshore sequences, Veevers (1984, 2000) 


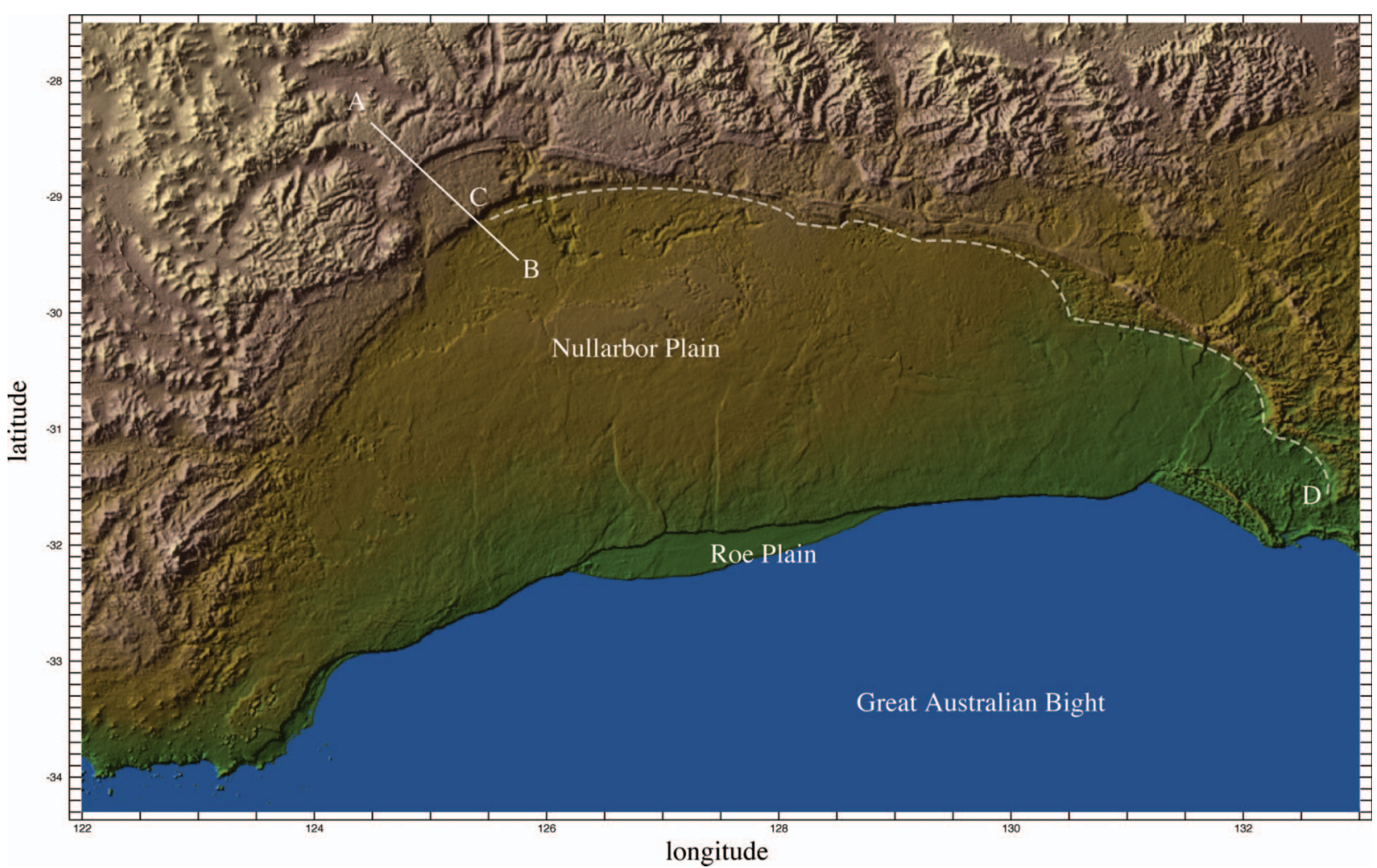

Figure 2 Shaded relief of the Nullarbor Plain showing various paleoshoreline features of Eocene to mid-Miocene age (>15 Ma) along its northern margin. The Roe Plain is a Pliocene feature. North-south-trending faults crossing the Nullarbor Plain have cumulative throws of up to $20 \mathrm{~m}$.

placed Cenozoic shorelines at between 0 and $50 \mathrm{~m}$ beneath sea-level around much of the northern and eastern coast (Figure 1). Probably the best constraints come from the Karumba Basin, around the Gulf of Carpentaria, where a number of onshore exposures along the western coast of the Cape York Peninsula place the position of Miocene and Pliocene shorelines close to the present-day shoreline (Doutch 1976; Smart et al. 1980). A possible exception to this is provided by the report of scattered outcrops of Miocene limestone on the Barkly Tablelands in the Northern Territory, $\sim 500 \mathrm{~km}$ southwest of the Gulf of Carpentaria at elevations of $\sim 250 \mathrm{~m}$ ASL (Lloyd 1968; see also Veevers 1984, 2000). Lloyd (1968) suggested a possible marine influence on the basis of the occurrence of the euryhaline foraminifera, Ammonia beccarii, which is known as a marginal-marine species. It is also known from lagoon and inland lake systems (Cann et al. 1999) and thus its environmental significance is doubtful. The absence of any diagnostic marine fauna amongst the species reported by Lloyd (1968), together with the limited extent of outcrop suggests these more likely formed part of a system of terrestrial lake deposits (Doutch 1976), rather than a widespread marine incursion across Northern Australia.

The pattern of Cenozoic marine inundation of the continent is further informed by the absence of marine sediments from a number of low-lying interior basins. For example, the Eyre Basin with a present-day minimum elevation of $10 \mathrm{~m}$ BSL is confined by a sill at $\sim 80 \mathrm{~m}$ ASL from the Torrens Basin that, in turn, is separated from Spencers Gulf by a sill at $\sim 40 \mathrm{~m}$ ASL. Despite this low elevation, neither the Torrens Basin nor the Eyre Basin has any record of Cenozoic marine sedimentation. Intriguingly, the present-day divide between the Torrens and Eyre Basins is marked by deposits of a large paleo-lake, Lake Billa Kalina, of probable Late Miocene age (Callen \& Cowley 1998), clearly evidenced by a set of arcuate strandlines along its former eastern shoreline (Figure 7). At its maximum size of $\sim 15000 \mathrm{~km}^{2}$ this lake would seem to require a catchment that included much of the present Eyre and Torrens Basins. In this region, a post-Late Miocene topographic inversion of $\sim 130 \mathrm{~m}$, over a wavelength of order $10^{2} \mathrm{~km}$, is implied by the difference in elevation between the base of the Billa Kalina deposits at $\sim 120 \mathrm{~m}$ ASL and the present elevation of Lake Eyre (Figure 8).

In summary, arguably the most extraordinary feature of the Australian Cenozoic stratigraphic record is the profound asymmetry in the pattern of preservation of marine sediments at the scale of the continent. This pattern demands a relative north-down, south-up tilting. Intriguingly the asymmetric pattern of Early to midCenozoic onshore sediments around Australia is mirrored by elevations in Holocene shoreline elevations, which tend to be elevated along the southern margin relative to the northern margin by several metres (Belperio et al. 2002) suggesting that this tilting may continue to the present day. In detail, the pattern of 
Figure 3 Topographic profiles across the Eucla Basin showing interpreted inundation extents at various times in the Cenozoic (see Figure 2 for profile locations). Topographic data form the Shuttle Radar Topographic Mission 3-arc second data. (a) Section A$\mathrm{B}$ normal to the paleoshorelines in the northwestern part of the basin (profile length is $130 \mathrm{~km}$ ). (b) Section C-D parallel to the interiormost limits of the Nullarbor Plain showing the interpreted limit of the Miocene (line-of-sight profile length is $760 \mathrm{~km}$ ). Much of the noise in the signal can be attributed to secondary erosional processes, and at least in one case, subsequent faulting. However, the greatest power is in the lowest frequency component (indicated by the grey band) at wavelengths of order $10^{3} \mathrm{~km}$, implying a deep mantle origin related to dynamic topography.
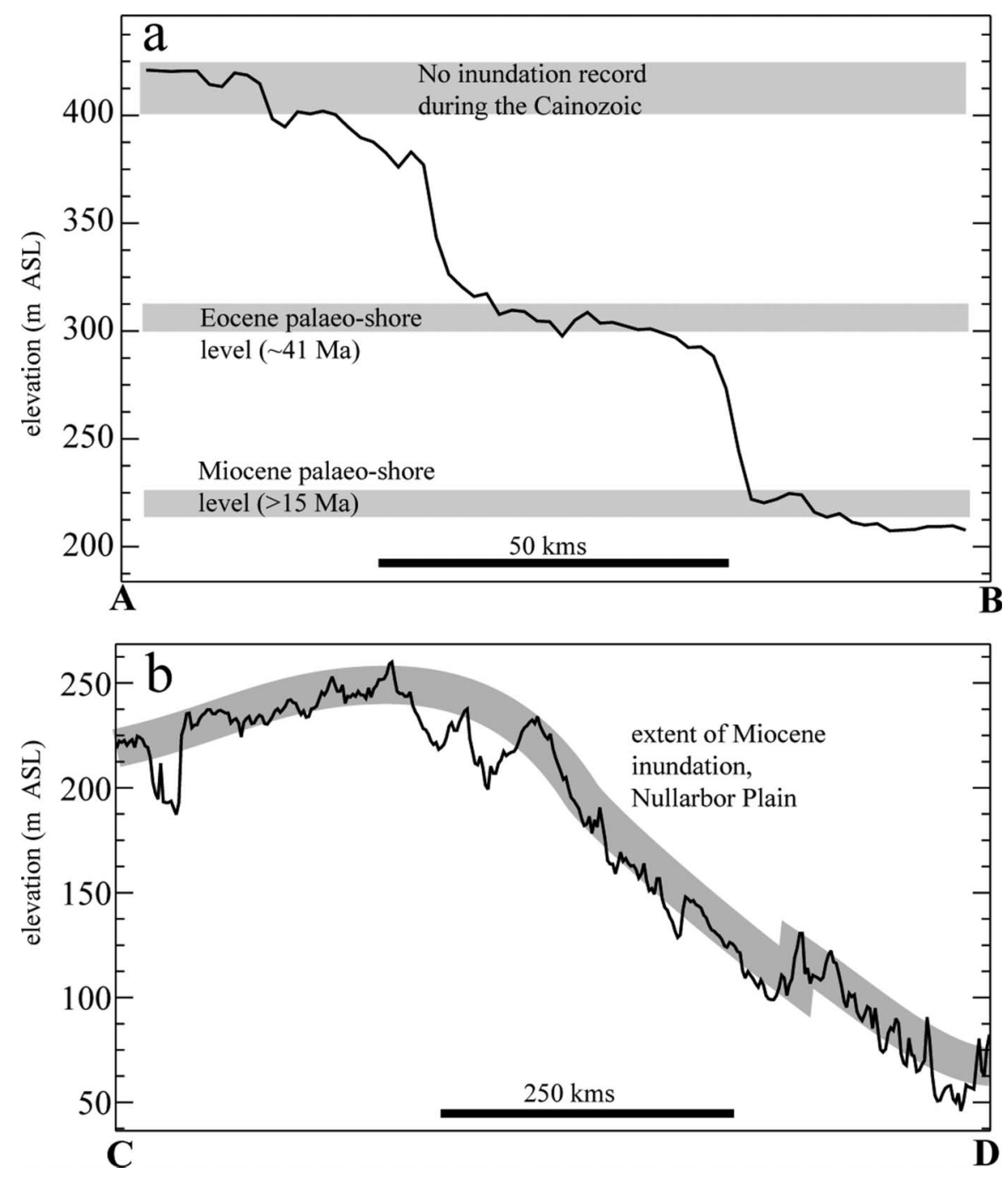

apparent tilting is informed by the systematic variation in elevation of paleoshoreline features across the Nullarbor that suggests the southwest part of the continent has risen significantly relative to the southeast. Thus, the distribution of preserved onshore marine sediments suggest a tilt axis that trends northwest-southeast across the continent from the northern part of Western Australia through to the southeast corner of the continent. Smaller wavelength variations in the distribution and elevation of Cenozoic sediments point to deformation modes operating at the sub-continental scale, associated with faulting at the $10^{1} \mathrm{~km}$ wavelength and undulations at the $10^{2} \mathrm{~km}$ wavelength scales. In the following sections we address the causative factors associated with each of these distinct deformation modes.

\section{LONG-WAVELENGTH DEFORMATION MODE (ORDER $10^{3} \mathrm{~km}$ )}

As outlined in the previous section even a cursory appreciation of the distribution of the onshore Cenozoic marine record of the Australian continent reveals a startling asymmetry between the southern and northern
Australian margins. While a number of authors have proposed subsidence of the Australian continent over the Cenozoic, relative to other continents (Bond 1978; Veevers 1984, 2000), there has been surprisingly little scientific attention focused on the asymmetry. One of the few comments comes not from the scientific literature but from the popular science writing of Bill Bryson (2003 p. 164) who, in A short history of nearly everything, astutely observed 'Australia meanwhile has been tilting and sinking. Over the past 100 million years, as it has drifted north towards Asia, its leading edge has sunk by nearly 200 metres. It appears Indonesia is very slowly drowning and dragging Australia down with it.' Much of this insight seems to derive from Gurnis (2001), who provided an excellent introductory account of how convection in the Earth's mantle impacts on the surface elevation of the continent, arguing that throughout the Cenozoic dynamic processes in the mantle have caused Australia to sink by at least $200 \mathrm{~m}$. The notion of a Cenozoic sinking was motivated in part by Bond (1978) who derived estimates of relative vertical motions of the continents by comparing changes in the proportion of apparent flooding taking into account the hypsometry. Because of the use of an index based on the proportion of continent 


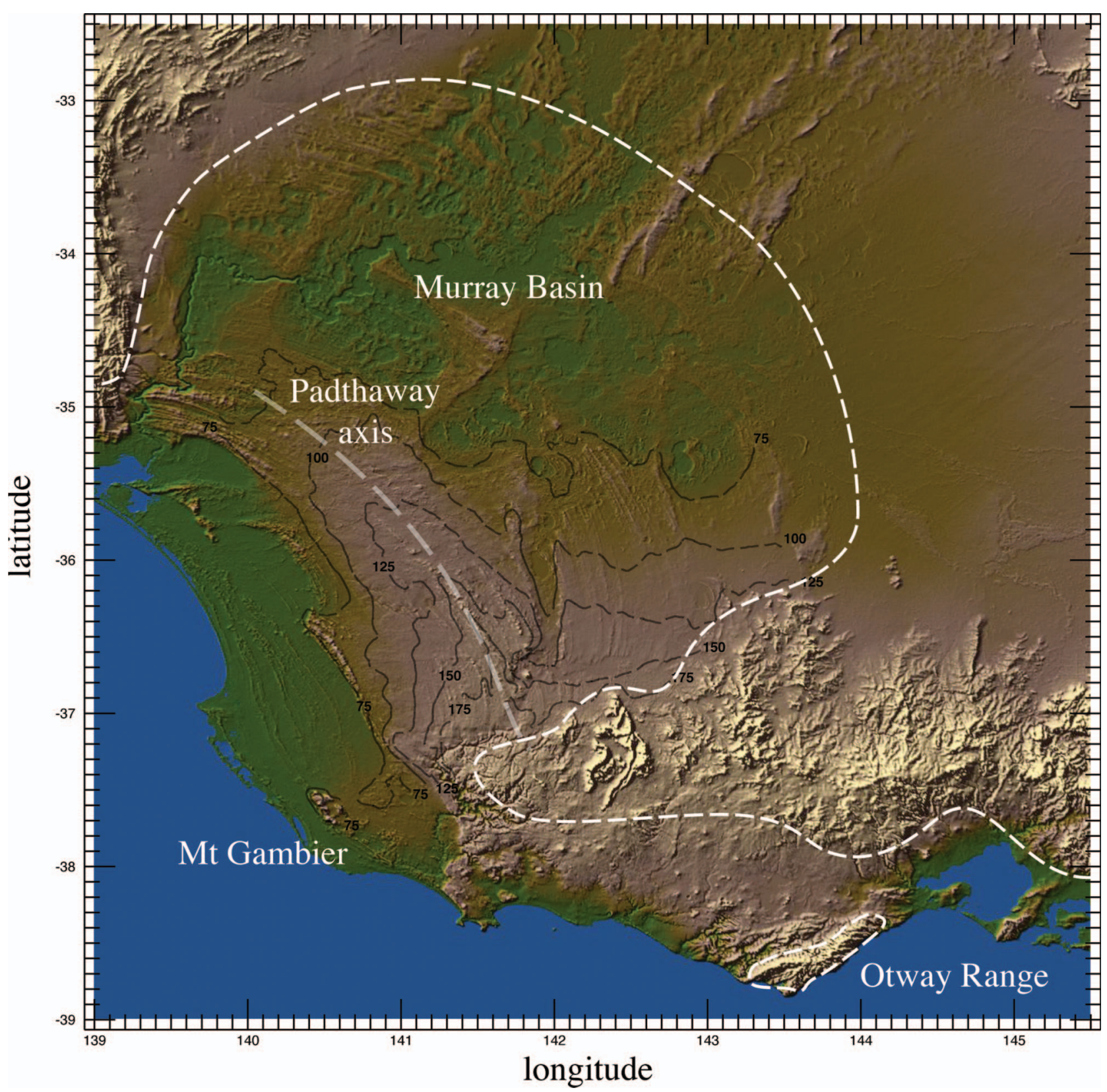

Figure 4 Shaded relief image of the Murray Basin and western Victorian highlands. The dashed line shows the approximate limits of marine inundation prior to $15 \mathrm{Ma}$ and again at $c a 6 \mathrm{Ma}$. In the internal parts of the basin this inundation coincides with the $70 \mathrm{~m}$ contour, but reaches elevations as high as $180 \mathrm{~m}$ along the Padthaway axis. The arcuate ridge systems in the Murray Basin form part of the Pliocene-Quaternary regressive strandplain with the Padthaway axis rising by up to $110 \mathrm{~m}$ relative to the internal parts of the basin since the Late Pliocene (see Figure 5 for details).

flooding, Bond (1978) was only able to provide estimates of average continental elevation changes. As we have outlined, the distribution of Cenozoic marine sediments indicates that the pattern of long-wavelength deformation of the Australian continent is far more complex than a simple sinking. Indeed, in as much as eustatic sea-levels are unlikely to have been much greater than about 100-150 m ASL over the last $43 \mathrm{Ma}$, much of the southwestern margin of the Australian continent must have risen in an absolute sense, rather than sunk. In this section we provide a framework for understanding the long wavelength tilting of the continent in terms of the concept of dynamic topography.
Variations in the elevation of the Earth's surface are supported either by the isostatic compensation of density anomalies within the lithosphere or by dynamic processes beneath the lithosphere. At short wavelengths (order $10^{1} \mathrm{~km}$ ) variations in surface elevation mostly relate to the compensation of lithospheric density anomalies, and thus are essentially isostatic in nature. At wavelengths comparable to the thickness of the lithosphere (order $10^{2} \mathrm{~km}$ ) deviations from local isostasy can usually be related to flexural strength of the lithosphere, and give rise to the notion of regional isostasy. At the scales of order $10^{3} \mathrm{~km}$, compatible with the dimensions of mantle circulation, surface elevations 

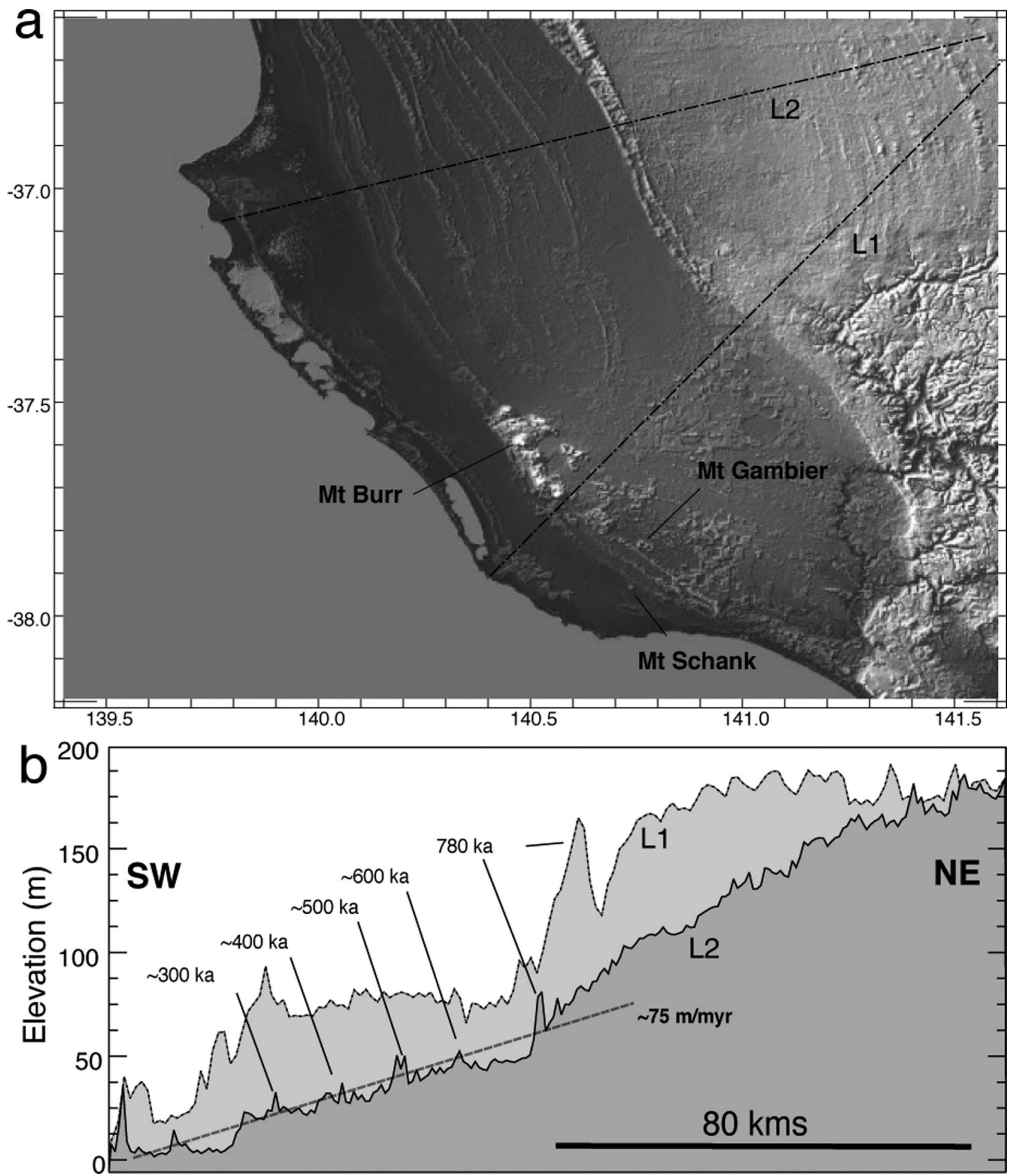

Figure 5 (a) Shaded relief image of a portion of the Murray Basin, showing Quaternary beach ridges on the Gambier Plain. (b) The age structure of shoreline features (Murray-Wallace et al. 2001) indicate uplift of the Padthaway ridge at a rate of at least $75 \mathrm{~m} / \mathrm{Ma}$ over the last $780 \mathrm{ka}$. Mt Burr, Mt Gambier and Mt Schank are sites of Quaternary mafic volcanism, and represent the youngest and westernmost limits of an active field of Neogene volcanism that extends eastwards some $400 \mathrm{~km}$ to Melbourne in Victoria, straddling the southern flanks of the western Victorian highlands.

may reflect variations in vertical stress transmission between convective mantle and the lithosphere, termed dynamic topography. In the general case of steady convection in the mantle, the mass anomaly that drives the mantle flow should be associated with a deflection of a density interface (such as the upper or lower surface) sufficient to compensate the driving anomaly (Richards \& Hager 1984) (Figure 9). The nature of the dynamic topography signal has been subject to significant debate (Gurnis 1993; Wheeler \& White 2000), partly because we 


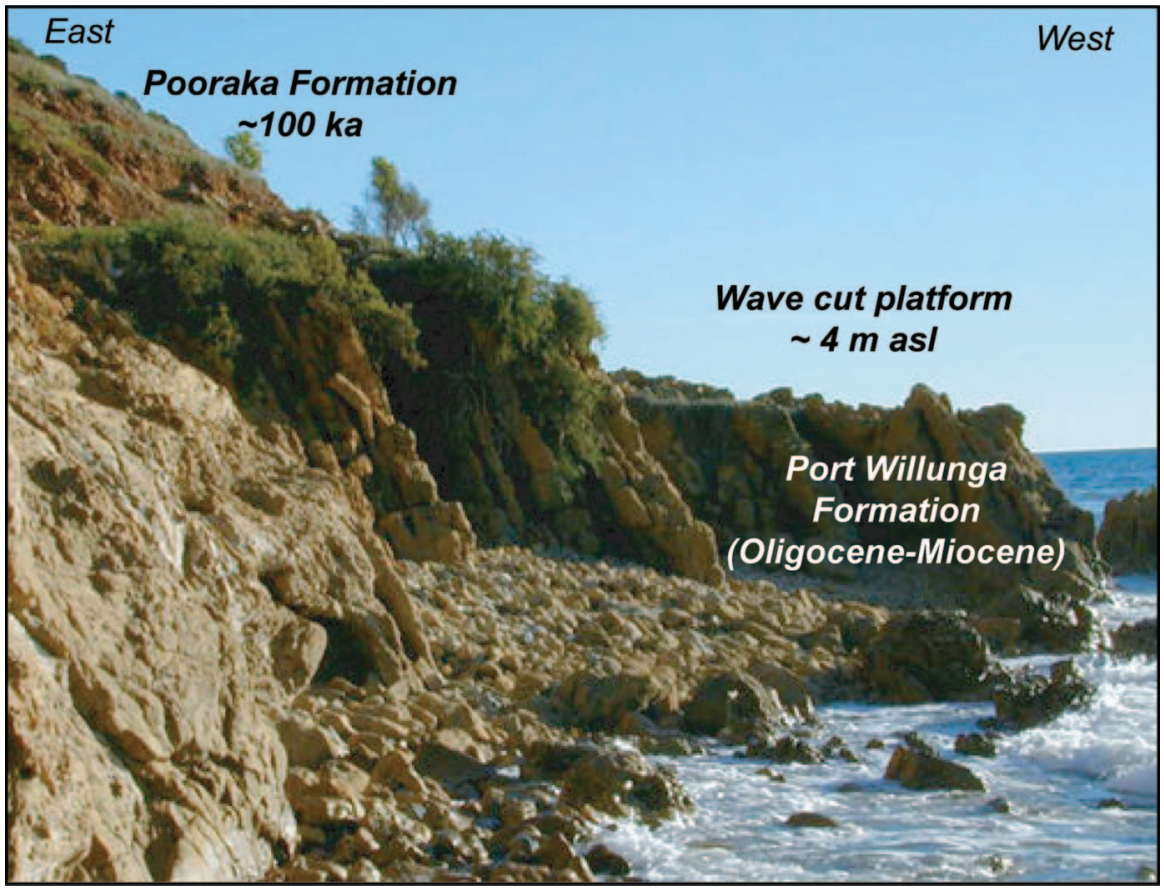

Figure 6 Near-vertically dipping Oligocene-Lower Miocene Port Willunga Limestone exposed on beach platform at Sellicks Beach south of Adelaide in the footwall to the Willunga Fault $\left(35^{\circ} 21^{\prime} 10^{\prime \prime} \mathrm{S}\right.$, $138^{\circ} 26^{\prime} 04^{\prime \prime} \mathrm{E}$ ). On the hangingwall block, $\sim 5 \mathrm{~km}$ to the southeast, correlative sequences occur at elevations up to $170 \mathrm{~m}$ ASL in the Myponga Basin (Sandiford 2003a).

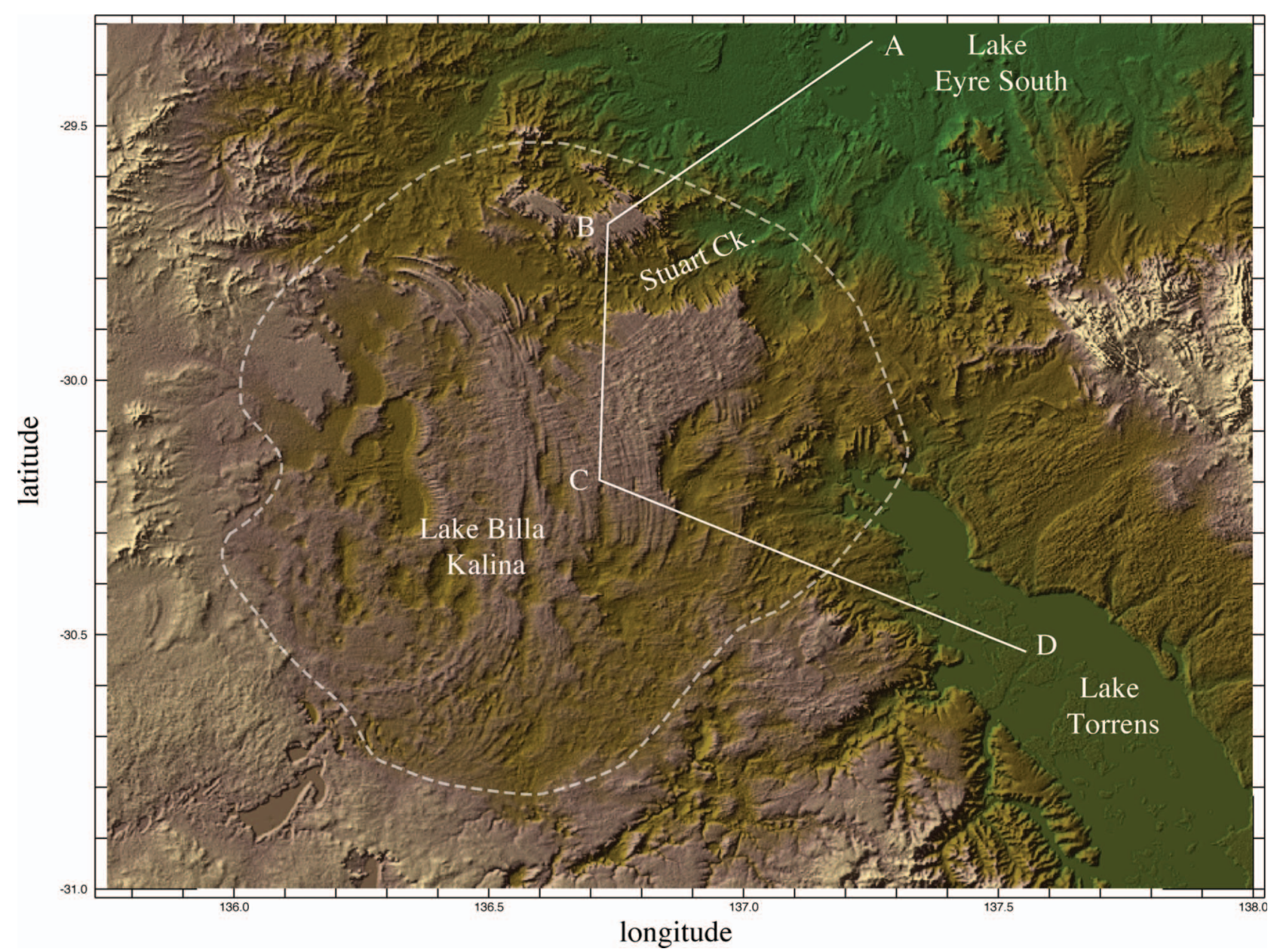

Figure 7 Shaded relief image of Billa Kalina Basin, South Australia, showing distinctive arcuate paleoshoreline features of Lake Billa Kalina of probable Miocene age. The inferred approximate maximum extent of the lake is indicted by the dashed line, based on limits of relict paleoshorelines. Note that Lake Billa Kalina is now perched on the present drainage divide between the Torrens and Eyre Basins (see Figure 8) implying significant topographic inversion since the lake formation. The topographic profile along the line A-B-C-D is shown in Figure 8. 
Figure 8 Topographic profile along line A-B-C-D in Figure 7, showing a significant topographic inversion since the formation of the Billa Kalina Lake of presumed of Miocene age (Callen \& Cowley 1998).

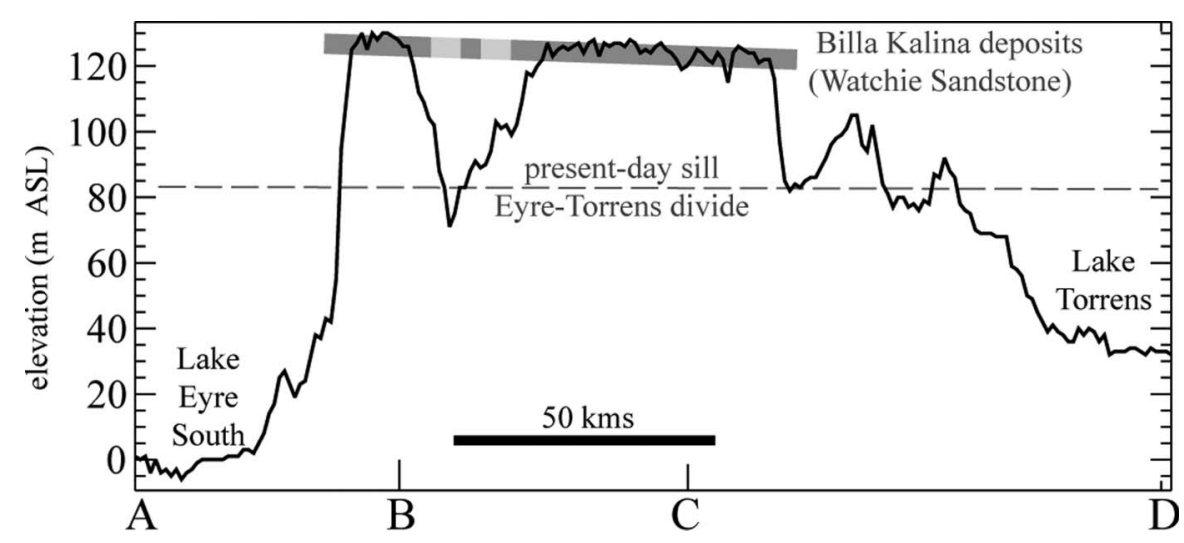

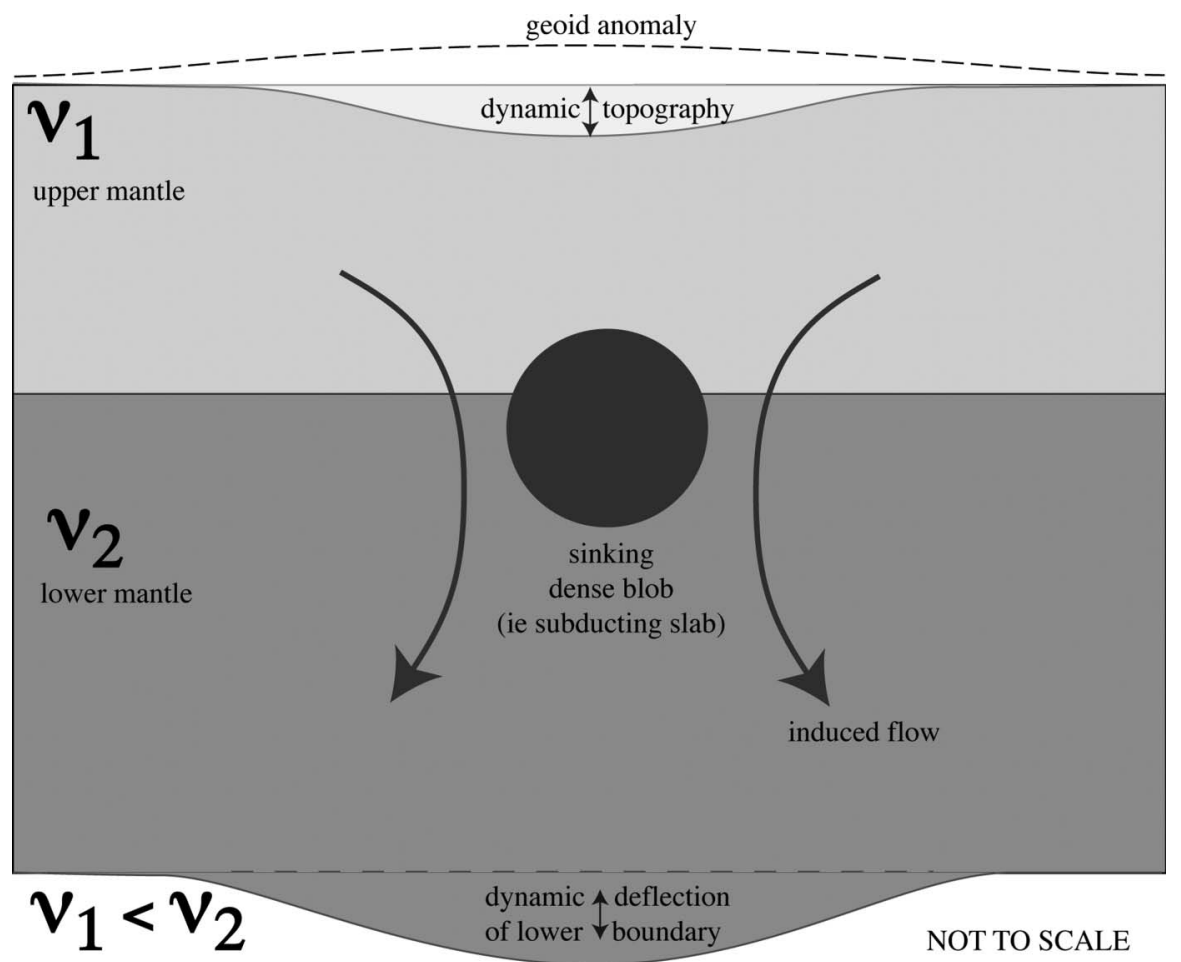

Figure 9 Schematic illustration of dynamic topography in the Earth, driven by a density anomaly in the convective mantle such as a subducting slab. The induced flow will deform the boundaries of the convective layer in a way that reflects the viscosity structure of the convective layer. The pattern of dynamic topography (a measure of the deformation of the upper surface) and geoid (a measure of the driving density anomaly and associated compensating deflections on both lower and upper surfaces) imply a lower mantle some 30 times more viscous than the upper mantle (Hager 1984; Richards \& Hager 1984; Gurnis 1993). A continent, such as Australia, moving towards a long-lived zone of subduction will feel a real tilting caused by the dynamic topographic subsidence as well as an apparent tilting caused by the increasing height of the geoid. The amplitude of the dynamic topographic signal is several times that of the geoid signal. The horizontal length scales are of the same order as the thickness of the convecting layer and therefore of order $10^{3} \mathrm{~km}$. Note that for clarity the deflections and geoid anomalies of order $10^{2}-10^{3} \mathrm{~m}$ are not to scale.

do not fully understand the mechanical properties of the deeper mantle in sufficient detail to provide realistic physical simulations. Numerical modelling studies of mantle convection with overlying plates frequently predict a dynamic topographic signal of several kilometres (Lithgow-Bertelloni \& Gurnis 1997). However, such predictions seem inconsistent with the record of continental interiors that show them to have been immune from complete inundation, with some authors suggesting that dynamic effects have no significant role on the Earth's surface topographic field (Wheeler \& White 2000).

The expected pattern of dynamic topography should relate primarily to the planform of mantle circulation, with zones of mantle downwelling characterised by dynamic topographic lows and zones of upwelling characterised by dynamic topographic highs. Regions above zones of persistent downwelling, such as regions associated with subduction, are characterised by dynamic topographic lows, as is illustrated by the 
Sunda Block to the north of Australia, which constitutes one of the most submerged regions of continental crust on the modern Earth. Such a dynamic topographic effect is arguably the reason for the relative broad continental shelf along Australian northern margin, that contrasts with the generally much narrower southern shelf. Because the density anomalies driving mantle circulation are at depths of order $10^{3} \mathrm{~km}$ in the mantle, the expected spatial scale of the dynamic topographic expression is also of order $10^{3} \mathrm{~km}$ (Figure 9). Thus a continent that has a long-lived history of movement towards a zone of persistent subduction, such as Australia, should be expected to experience a tilting downwards in the sense of plate motion. The geological indicators of this tilting will be further augmented by the fact that downwelling zones are not only characterised by a dynamic topography low but also by a geoid high. This association is attributed to the impact of the viscosity structure of the mantle on the way in which the dynamic topographic response is partitioned between upper and lower boundaries of the convective mantle (Richards \& Hager 1984) (Figure 9). In Australia, the observed long-wavelength increase in the geoid height from south-southwest to north-northeast is $\sim 60 \mathrm{~m}$ (Figure $10 \mathrm{a}$ ).

The notion that the continental-scale asymmetry in the Cenozoic stratigraphic record of Australia is a dynamic topographic signal is supported by the general parallelism of the inferred tilt axis and the long-wavelength geoid (Figure 10a), and is readily explicable in terms of the northward motion of the continent towards the equatorial western Pacific realm. Since this region has been the site of plate convergence and subduction throughout the Cenozoic (LithgowBertelloni \& Richards 1998), it is a region of low dynamic topography and high geoid extending over many thousands of kilometres. Thus the downward tilting of the northern part of the Australian continent inferred from the absence of onshore Cenozoic shorelines can be interpreted to represent the combination of a real dynamic subsidence as well as an increase in sea-level height associated with the elevated geoid. The later effect contributes $\sim 20 \mathrm{~m}$ per $1000 \mathrm{~km}$ of northward motion, and given that the total apparent subsidence must exceed the eustatic sea-level fall over the Cenozoic, the contribution of the dynamic subsidence is likely to be about $100 \mathrm{~m}$ along the north coast of Australia.

The absolute uplift of the southwestern part of the continent suggests that this part of the continent has moved away from a dynamic low over the last $15 \mathrm{Ma}$. That such a dynamic topographic low exists to the south of Australia is indicated by the anomalously low elevation of the mid-ocean ridge along the Australian Antarctic discordance, which contributes one of the lowest residual bathymetric anomalies known from the oceans. Gurnis et al. (1998) have argued that this low
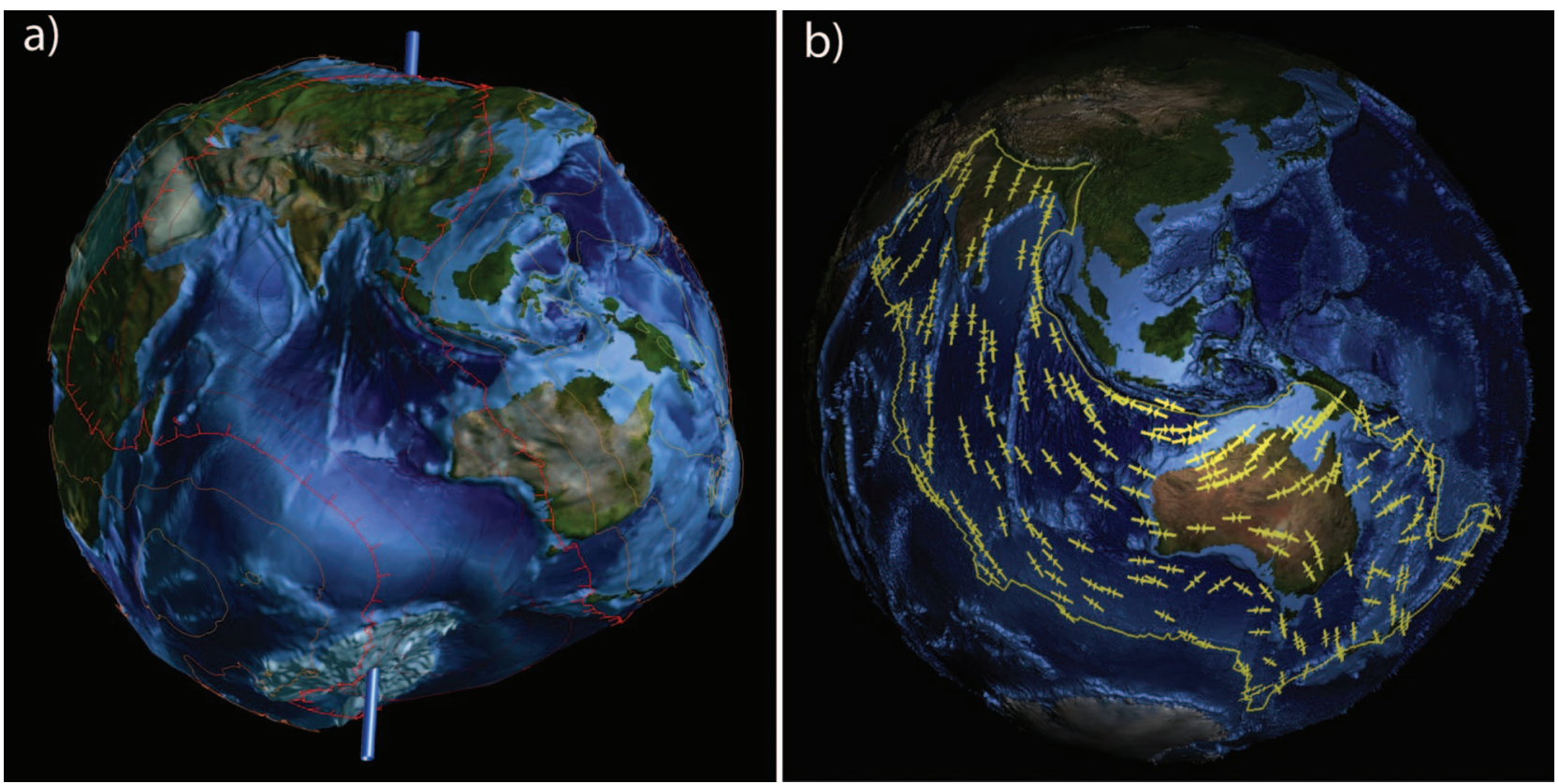

Figure 10 (a) Representation of the variation in the geoid field across Australia, illustrated by mapping a satellite-derived image of the Earths surface onto a greatly exaggerated view of the geoid field. The magnitude of the geoid field variations are indicated by the contours with $20 \mathrm{~m}$ intervals, with the geoid field rising $\sim 90 \mathrm{~m}$ across Australia from southwest to northeast. The trend of the geoid anomaly corresponds to the apparent tilt axis derived from the longest wavelength variations in elevation of Cenozoic nearshore deposits around the Australian coastline. The slightly north-northeast trajectory of the Indo-Australian Plate means the Australian continent has moved progressively into a region of higher geoid contributing an apparent north-side down tilting. (b) The pattern of in situ stress in the Indo-Australian Plate deduced by plate-scale modelling studies (Coblentz et al. 1995, 1998). Arrows indicate the orientation of the maximum horizontal stress vector (SHmax). Note how the complex pattern of stress in Australia is controlled by trends that point respectively to New Guinea (in the northeast), New Zealand (in the southeast) and to a west-trending arcuate pattern (in the west) that links eventually to the Himalayas. This pattern reflects the role of these collisional orogenic systems in providing the resistive forces that balance the forces of ridge-push and slab-pull that drive the plate northwards. 
reflects the existence of a relict of a former slab, now elevated above the mantle transition zone due to the opening of the Southern Ocean. They argued that this piece of slab is a remnant of a subduction system to the east of the Gondwana margin, and showed how dynamic topography associated with this slab system provides an elegant explanation for anomalous Cretaceous subsidence in the Eromanga Basin in central-east Australia due to Australia's then eastward motion. By analogy, the Cenozoic northward motion of Australia away from this anomalous mantle, that to this day helps lower the bathymetry in the southern Ocean, will have caused a dynamic topographic uplift of Australia's southern margin, estimated to be up to $\sim 200 \mathrm{~m}$ in amplitude. The nature and significance of the Cenozoic tilting record of Australia is discussed in further detail by Sandiford (2007).

\section{SHORT-WAVELENGTH DEFORMATION MODE (ORDER $10^{1} \mathrm{~km}$ )}

At the short wavelengths, a seismogenic deformation is indicated by the record of mild faulting evidenced in most onshore Cenozoic basins. As summarised in Sandiford (2003a, b) and Sandiford et al. (2004), the distribution of this faulting in southeastern Australia correlates with the distribution of active seismicity, while the style and orientation of faults is largely consistent with the inferred in situ stress field (Celerier et al. 2005; Quigley et al. 2006). More recently, Hillis et al. (2008) have shown similar relationships apply in the North West Shelf region, including the Cape Range.

A useful framework for understanding this ongoing faulting is provided by the modeling studies of Coblentz et al. $(1995,1998)$ who have shown that the pattern of in situ stress in Australia is best explained with reference to the balance of forces operating at the plate-scale. The Coblentz et al. (1995, 1998) analysis highlights the role of collisional forces generated by the Himalayan, New Guinea and New Zealand collision zones in balancing plate driving forces of ridge push and slab pull, with the SHmax aligning to a near-orthogonal direction in the vicinity of each of these collisional orogens (Figure 10b). These modeling studies provide for testable hypotheses, in-as-much as the nature of plate forcing stemming from these collisions has changed considerably through the Cenozoic. For example, the convergence between the Pacific and IndoAustralian Plates responsible of the Southern Alps collision zone in New Zealand is related to progressive changes in plate rotation poles in the period 10-5 Ma (Sandiford et al. 2004). That southeast Australia feels this change in plate-boundary forcing is corroborated by the evidence for increased faulting activity commencing at around $6 \mathrm{Ma}$ (Sandiford et al. 2004).

\section{INTERMEDIATE-WAVELENGTH DEFORMATION MODE (ORDER $10^{2} \mathrm{~km}$ )}

Arguably the most enigmatic signal of Cenozoic deformation is provided by the evidence for developing undulations with amplitude of order $10^{2} \mathrm{~m}$ and wavelength of order $10^{2} \mathrm{~km}$, as perhaps best illustrated by the Padthaway Ridge in southeast South Australia. In another setting, Celerier et al. (2005) noted that the long-wavelength pattern of deformation of the Flinders Ranges and the surrounding basins was characterised by an similar undulation pattern of $\sim 400 \mathrm{~m}$ amplitude (Figure 11), with the implied downward deflection of the Torrens Basin providing an explanation for the absence of Early to mid-Cenozoic marine inundation. Similar wavelength undulations may also have contributed to the change in the location of the depocentre from the Billa Kalina to the Eyre and Torrens Basins (Figures 7, 8). Other indicators that such undulations are a relatively widespread mode of Cenozoic
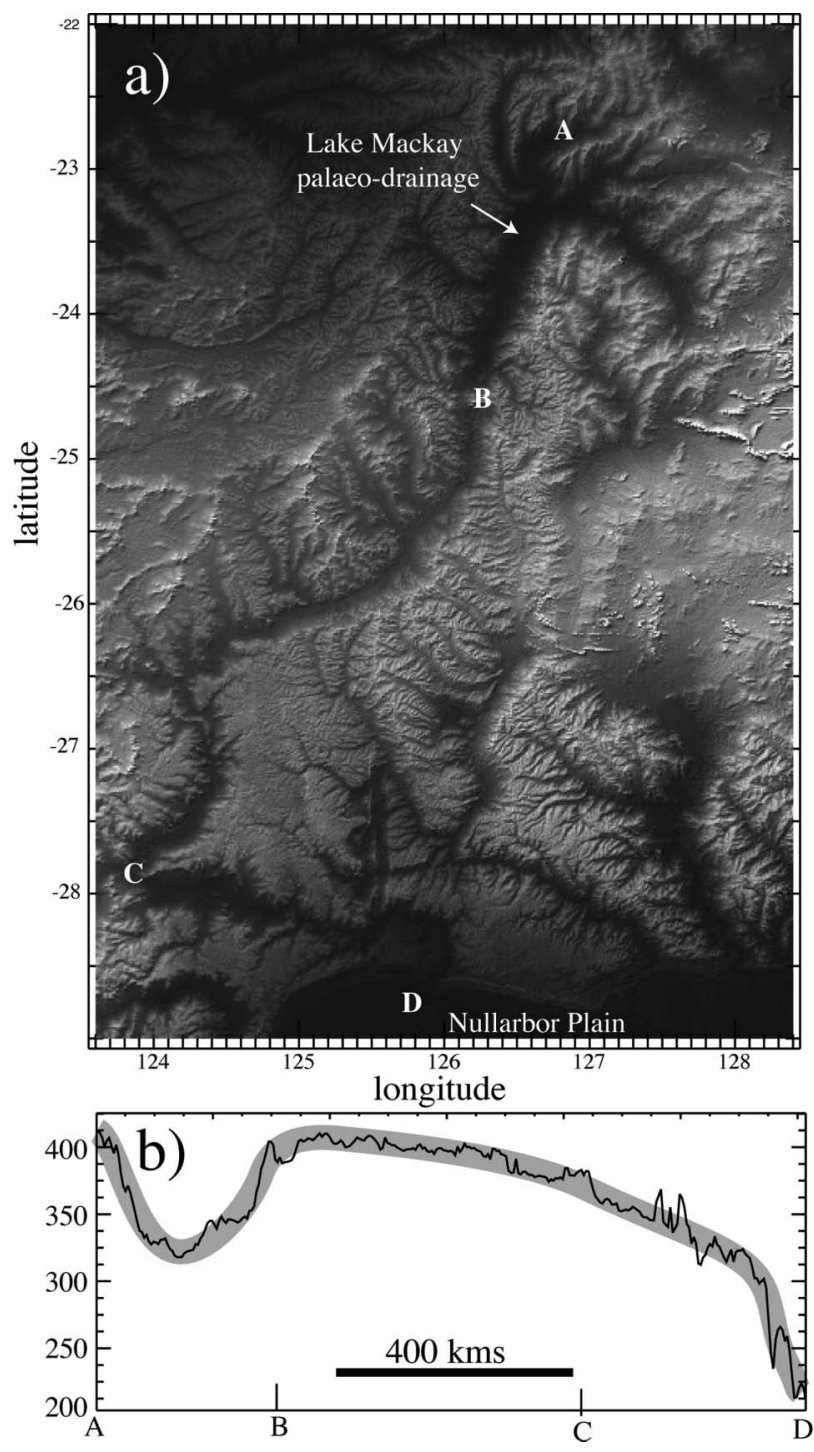

Figure 11 (a) Topographic and (b) Bouguer gravity profiles across the Flinders Ranges and surrounding low-lying basins combined with models of thin elastic-plate deformation for various flexural parameters (from Celerier et al. 2005). The positive coherence between topography and gravity precludes an isostatic mechanism for the support of the topography and suggests a lithospheric buckling mode at wavelengths of order $10^{2} \mathrm{~km}$ (Celerier et al. 2005). 
deformation in the Australian continent are to be found in western desert country around Lake Mackay, where a significant section of the northern part of the paleodrainage system appears internally confined, as much as $80 \mathrm{~m}$ below the level of formerly downstream reaches (Figure 12). Further south, in the Bremer Basin, immediately west of the Eucla Basin, marine sediments now occur to elevations now beneath about $180 \mathrm{~m}$ ASL, significantly lower than equivalent sequences in the western Nullarbor Plain and associated incursions into the Lefroy paleodrainage, reflecting deformation about a west-southwest-east-northeasttrending axis variously termed the 'Jarrahwood Axis' or 'Ravensthorpe Ramp' (Cope 1975; Clarke 1994; de Broekert \& Sandiford 2005).

Celerier et al. (2005) have proposed that the longwavelength pattern of deformation associated with Flinders Ranges and surrounding anomalously low basins (such as the Torrens and Frome Basins) could be understood in terms of lithospheric-scale $\left(10^{2} \mathrm{~km}\right)$ buckling phenomenon (Figure 11). This interpretation stems in part from the observed positive coherence between topography and Bouguer gravity fields (Figure 11), as well as regional structural trends on deformed surfaces. As such, the deformation is analogous to the proposed deformation of the central Indian Ocean lithosphere which commenced at around $8 \mathrm{Ma}$ (Gerbault 2000), and which has been attributed to increases in intraplate stress levels due to an increase in plate forcing induced by the rise in the
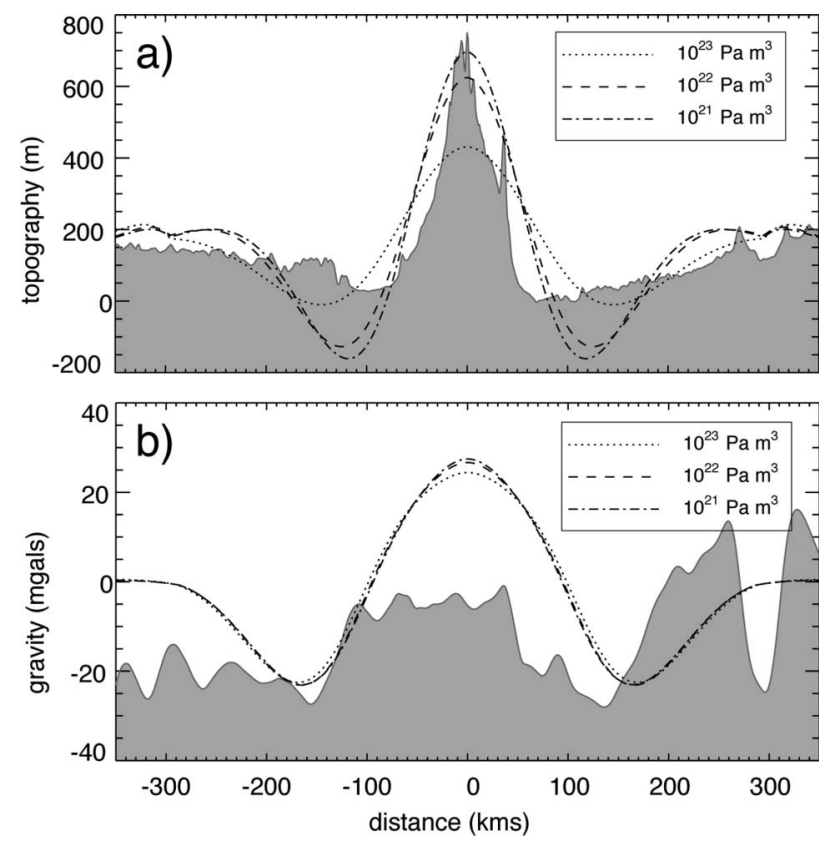

Figure 12 Shaded relief image of the Lake Mackay paleodrainage, Western Australia, with associated channel profile. The upper reaches of this paleodrainage, between points $\mathrm{A}$ and $\mathrm{B}$, now drain internally to depths $\sim 80 \mathrm{~m}$ lower than the highest parts of the formerly downstream reach, between points $\mathrm{B}$ and $\mathrm{C}$. To the extent that the surface expression of this paleodrainage has not been significantly altered by differential filling, the drainage must have been deranged as a consequence of an order $10^{2} \mathrm{~km}$ undulation.
Himalayan-Tibetan orogen at this time (Martinod \& Molnar 1995). For the Flinders Ranges, the notion of lithospheric scale buckling along a north-south axis is consistent with the prevailing east-west SHmax trend in this part of the continent. Elsewhere, the undulation axes trends are less explicable in terms of the prevailing stress field, and the causative factors are less clear. For example, the Padthaway axis is roughly parallel to the inferred southeast SHmax trend (Coblentz et al. 1995, 1998). Here, Demidjuk et al. (2007) have suggested the uplift reflects a dynamic mantle process associated with a small-scale, secondary mode of convection beneath the Australian Plate that has sourced the Late Neogene mafic volcanism along the Gambier Plain (Figure 5) as well as along the southern flanks of the western Victorian highlands. Resolving the mechanisms responsible for this enigmatic intermediate-wavelength pattern of surface deformation remains a significant challenge.

\section{CONCLUSIONS}

(1) The Australian continent is well known for its relative tectonic stability, consistent with its intraplate setting. However, it is also the fastest moving continent in arguably one of the most dynamic of the Earth's large tectonic plates, and therefore has not been totally immune from tectonic activity.

(2) The ongoing role of tectonism is evidenced by a variety of indicators including variations in the extent of marine inundation around the Australian continent during the Cenozoic. Variations in the extent of marine inundation around the Australian continent during the Cenozoic indicate three distinct deformation modes. Each of these deformation modes can, to varying degrees, be allied to the plate-scale dynamics, and reflects the fact that Australia is a relatively highly stressed, fast moving continent in a complex plate.

(3) Of particular note is Australia's dynamic topographic response due to its northward motion towards the subduction realm of the western Pacific, as well as its passage across a complexly structured mantle. This northeast-down, southwest-up tilting at the continental scale has an amplitude of about $300 \mathrm{~m}$, and provides a unique signal of how dynamic processes in the Earth's convective mantle impact on the surface topographic field.

(4) Understanding the patterns associated with each of these deformation modes provides a tectonic framework against which the broader significance of the Australian Cenozoic record for such things as the global eustatic record must be evaluated.

\section{ACKNOWLEDGEMENTS}

This work has been supported by ARC Discovery grants DP0558705, DP0558705 and DP556133, and has benefited from discussions with Mike Gurnis, Malcolm Wallace, Dan Clark, Jim Bowler, Dietmar Müller and Baohong Hou. 


\section{REFERENCES}

Belperio A. P., Harvey N. \& Bourman R. P. 2002. Spatial and temporal variability in the Holocene sea-level record of the South Australian coastline. Sedimentary Geology 150, 153-169.

Bond G. C. 1978. Evidence for late Tertiary uplift of Africa relative to North America, South America, Australia and Europe. Journal of Geology 86, 47-65.

BOURMAN R. P. \& LiNDSAY J. M. 1988. Timing extent and character of late Cainozoic faulting on the eastern margin of the Mount Lofty Ranges, South Australia. Transactions of the Royal Society of South Australia 113, 63-67.

BRown C. M. \& Stephenson A. E. 1991. Geology of the Murray Basin. Bureau of Mineral Resources Bulletin 235.

BRYson B. 2003. A Short History of Nearly Everything. Doubleday, London.

Callen R. A. \& Cowley W. M. 1998. Billla Kalina Basin. In: Drexel J. F. \& Preiss W. V. eds. The Geology of South Australia, Volume 2, The Phanerozoic, pp. 195-198. Geological Survey of South Australia Bulletin 54.

CanN J. H., Murray-Wallace C. V., Belperio A. P. \& BRENCHLEY A. J. 1999. Evolution of Holocene coastal environments near Robe, southeastern South Australia. Quaternary International 56, 81-97.

Celerier J., SANDiford M., HANSEn D. L. \& QUigley M. 2005. Modes of active intraplate deformation, Flinders Ranges, Australia. Tectonics 24, doi:10.029/2004\&C001679

Clarke J. D. A. 1994. Evolution of the Lefroy and Cowan palaeodrainage channels, Western Australia. Australian Journal of Earth Sciences 41, 55-68.

COBLENTZ D., SANDIFORD M., RichaRdSON R., ZHOU S. \& HiLLIS R. 1995, The origins of the Australian stress field. Earth and Planetary Science Letters 133, 299-309.

CoBlentz D., ZHOU S., Hillis R., RichaRdSON R. \& SANDIFORD M. 1998. Topography, plate-boundary forces and the Indo-Australian intraplate stress field. Journal of Geophysical Research 103, 919-931.

COPE R. N. 1975, Tertiary epeirogeny in the southern part of Western Australia. Geological Survey of Western Australia Annual Report for 1974, 40-46.

De BRoEkERT P. \& SANDIFoRD M. 2005. Buried inset-valleys in the eastern Yilgarn Craton, Western Australia: geomorphology, age and allogenic control, Journal of Geology 113, 471-493.

DemidjuK Z., Turner S., SANDIFord M., GeORge R., Foden J. \& ETHERIDGE M. 2007. U-series isotope and topographic constraints on mantle melting from the Newer Volcanic Province in South Australia. Earth and Planetary Science Letters 26, 517-533.

Dickinson J. A., WALlace M. W., Holdgate G. R., Gallagher S. J. \& THomas L. 2002. Origin and timing of the Miocene-Pliocene unconformity in southeast Australia. Journal of Sedimentary Research 72, 317-332.

DouTch H. F. 1976. The Karumba Basin, northeastern Australia and southern New Guinea. BMR Journal of Australian Geology \& Geophysics 1, 131-140.

GERBAULT M. 2000. At what stress level is the central Indian ocean buckling? Earth and Planetary Science Letters 178, 165-181.

GURNIS M. 1993. Phanerozoic marine inundation of continents driven by dynamic topography above subducting slabs. Nature 364, 589-593.

GuRNIS M. 2001. Sculpting the earth from inside out. Scientific American 284(3), 40-47.

GuRNIS M., MÜLleR R. D. \& MoRESI L. 1998. Cretaceous vertical motion of Australia and the Australian Antarctic Discordance. Science 279, 1499-1594.

HAGER B. 1984. Subducted slabs and the geoid: constraints on mantle rheology and flow. Journal of Geophysical Research $\mathbf{8 9}$, 6003-6015.

Hillis R. R., SANDiford M., Reynolds S. D. \& Quigley M. C. 2008. Present-day stresses, seismicity and Neogene-Recent tectonics of Australia's 'passive' margins: intraplate deformation controlled by plate boundary forces. In: Johnson, H., Doré A. G., Gatliff R. W., Holdsworth R. E., Lundon E. R. \& Ritchie J. D. eds. The nature and origin of compression in passive margins, pp. 71-89. Geological Society of London Special Publication 306.
Hou B., Alley N. F., Frakes L. A., Stoian L. \& Cowley W. M. 2006 Eocene stratigraphic succession in the Eucla Basin of South Australia and correlation to major regional sea-level events. Sedimentary Geology 183, 297-319.

Hou B., Frakes L. A., Alley N. F., Gammon P. \& Clarke J. D. A. 2003. Facies and sequence stratigraphy of Eocene valley fills in Eocene palaeovalleys, the eastern Eucla Basin, South Australia. Sedimentary Geology 163, 111-130.

Hou B., Frakes L. A., SANDiford M., Worrall L., KeEling J. \& Alley N. F. 2008. Cenozoic Eucla Basin and associated palaeovalleys, southern Australia-climatic and tectonic influences on landscape evolution, sedimentation and heavy mineral accumulation. Sedimentary Geology $\mathbf{2 0 3}$, 112-130.

Huntley D. J., Hutton J. T. \& PrescotT J. R. 1993, The stranded beach-dune sequences of south-east South Australia: a test of thermoluminescence dating, 0-800 ka. Quaternary Science Reviews 12, 1-20.

LithGOW-BERTELlONI C. \& GURNIS M. 1997. Cenozoic subsidence and uplift of continents from time-varying dynamic topography. Geology 25, 735-738.

LithGOW-BeRTELlONI C. \& RichaRdS M. 1998, The dynamics of Cenozoic and Mesozoic plate motions. Reviews of Geophysics $36,27-78$.

LlOyD A. R. 1968. Possible Miocene marine transgression in Northern Australia. Bureau of Mineral Resources Bulletin 80, 87-100.

MARTINOD J. \& MOLNAR P. 1995, Lithospheric folding in the Indian Ocean and the rheology of the oceanic plate. Bulletin de la Societe Geologique de France 166, 813-821.

Murray-Wallace C. V., Brooke B. P., CANN J. H., Belperio A. P. \& BOURMAN R. P. 2001. Whole-rock aminostratigraphy of the Coorong Coastal Plain, South Australia: towards a million year record of sea-level highstands Journal of the Geological Society of London 158, 111-124.

QUIGLEY M., CUPPER M. \& SANDIFORD M. 2006. Quaternary faults of southern Australia: palaeoseismicity, slip rates and origin. Australian Journal of Earth Sciences 53, 285-301.

Quigley M., SANDIFord M., Alimanovic A. \& Fifield L. K. 2007a. Landscape responses to intraplate deformation in the Flinders Ranges, South Australia: quantitative constraints from 10Be abundances. Earth and Planetary Science Letters 261, $120-133$.

Quigley M., SANDiford M., Fifield L. K. \& Alimanovic A. 2007b. Bedrock erosion and relief production in the northern Flinders Ranges, Australia. Earth Surface Processes and Landforms 32, 929-944.

QuILTY P. G. 1977. Cainozoic sedimentation cycles in Western Australia. Geology 5, 336-340.

RichARDS M. A. \& HAGER B. H. 1984. Geoid anomalies in a dynamic Earth. Journal of Geophysical Research 89, 5987-6002.

Roy P. S, Whitehouse J., Cowell P. J. \& OAKes G., 2000, Mineral sands occurrences in the Murray Basin, southeastern Australia. Economic Geology 95, 1107-1128.

SANDIFORD M. 2003a. Neotectonics of southeastern Australia: linking the Quaternary faulting record with seismicity and in situ stress. In: Hillis R. R. \& Müller R. D. eds. Evolution and dynamics of the Australian Plate, pp. 101-113. Geological Society of Australia Special Publication 22

SANDIFORD M. 2003b. Geomorphic constraints on the late Neogene tectonics of the Otway Ranges. Australian Journal of Earth Sciences 50, 69-80.

SANDIFORD M. 2007. The tilting continent: a new constraint on the dynamic topographic field from Australia. Earth and Planetary Science Letters 261, 152-163.

SANDIFORD M., WALLACE M. \& COBLENTZ D. 2004. Origin of the in situ stress field in southeastern Australia. Basin Research 16 , 325-338.

Smart J., Grimes K. G., Doutch H. F. \& Pinchin J. 1980. The Mesozoic Carpentaria Basin a and the Cainozoic Karumba Basin, North Queensland. Bureau of Mineral Resources Bulletin 202.

SPRIGG R. C. 1979. Stranded and submerged sea-beach systems of southeast South Australia and the aeolian desert cycle. Sedimentary Geology 22, 53-96.

VeEvers J. J. (Editor) 1984. Phanerozoic earth history of Australia. Clarendon Press, Oxford 
VEeVERS J. J. (Editor) 2000. Billion-year earth history of Australia and neighbours in Gondwanaland. GEMOC Press, Sydney.

Wallace M., Dickinson J. A., Moore D. \& SANDiford M. 2005 Late Neogene strandlines of Southern Victoria: a unique record of eustasy and tectonics in southeast Australia. Australian Journal of Earth Sciences 52, 277-295.
WILLIAMS G. E. 1973. Late Quaternary piedmont sedimentation, soil formation and palaeoclimates in arid South Australia. Zeitschrift für Geomorphologie 17, 102-125.

WHEELER P. \& WHITE N. 2000. Quest for dynamic topography: observations from Southeast Asia. Geology 28, 963-966.

Received 14 December 2006; accepted 28 January 2009 